REVIEW

\title{
Molecular pathology of prostate cancer
}

\author{
C Hughes, A Murphy, C Martin, O Sheils, J O'Leary
}

J Clin Pathol 2005;58:673-684. doi: 10.1136/jicp.2002.003954

The molecular pathology of prostate cancer is complex; not only are multiple genes involved in its pathogenesis, but additional environmental factors such as diet and inflammation are also involved. The exhaustive research into prostate cancer to date has demonstrated a complex interaction of multiple genes and environmental factors, some of which may be more important in individual prostate cancer cases. This is an exciting era, with the emergence of new investigative tools such as DNA microarray technology and the application of the field of proteomics to the study of human cancers. Knowledge of genetic changes underlying the initiation, development, and progression of prostate cancer is accumulating rapidly. With increasing knowledge, it may be possible to distinguish indolent from aggressive prostate tumours by molecular fingerprinting. This review discusses the most consistently reported molecular pathological findings in hereditary and sporadic prostate cancer, together with new concepts and technologies.

See end of article for authors' affiliations

Correspondence to:

Professor J O'Leary

Pathology Department, Coombe Women's Hospital, Dublin 8, Ireland; olearyii@tcd.ie

Accepted for publication 16 February 2005
$\mathrm{P}$ rostate cancer is the second leading cause of cancer deaths in men. It is not invariably lethal, however, and is a heterogeneous disease ranging from asymptomatic to a rapidly fatal systemic malignancy. The prevalence of prostate cancer is so high that it could be considered a normal age related phenomenon: in a Spanish study examining white Mediterranean men, 33\% of men in their 8 th decade had evidence of prostate cancer at necropsy and died with the disease, but not from it. Data from American postmortem studies show an even higher prostate cancer prevalence rate. ${ }^{1}$ In recent years, there have been large increases in the five year survival rates for prostate cancer, with a five year relative age standardised survival rate of $65 \%$ in England and Wales for the years 1996-9. This was the third highest survival rate of all cancers over this time period, with only testicular cancer and melanoma having better survival rates, and was around $11 \%$ higher than that for patients diagnosed during 1991-5.2

"The prevalence of prostate cancer is so high that it could be considered a normal age related phenomenon"

Unfortunately, this improvement does not reflect better treatment for prostate cancer. It largely reflects an increasing number of men being diagnosed with very early stage prostate cancer as a result of the widespread use of prostate specific antigen (PSA) testing. PSA is a protein produced by both normal and cancerous prostate cells and a high PSA value can be a sign of cancer. Most men diagnosed at a very early stage will die with prostate cancer but not from it; therefore, the survival rate has increased. The American Cancer Society recommends in its prostate cancer screening guidelines that men should be informed of what is known and what is uncertain about the benefits and limitations of early detection of prostate cancer, so that they can make an informed decision about testing. Therefore, the early diagnosis of prostate cancer through screening creates difficulties in predicting the outcome of individual patients. The difficulty is in distinguishing between clinically indolent prostate cancers, which will be asymptomatic, and aggressive prostate cancers with the potential to kill the patient. Gleason grading on histopathological examination is the best prognostic indicator to date in prostate cancer; however, interobserver variation can occur, grading on biopsies may not correlate with the prostatectomy specimen because of sampling problems, and cases of morphologically identical prostate cancer can behave differently.

This is an exciting era with the emergence of new investigative tools such as DNA microarray technology and the application of the field of proteomics to the study of human cancers. Knowledge of genetic changes underlying the initiation, development, and progression of prostate cancer is accumulating rapidly. With increasing knowledge it may be possible to distinguish indolent from aggressive prostate tumours by molecular fingerprinting. A clinical application of this knowledge would be that radical treatment and its associated morbidity could be avoided in prostate cancers that are unlikely to progress. Resources and radical treatment could be focused on prostate cancers with poor prognostic indicators. In this review, we shall discuss the most consistently reported molecular pathological findings in prostate cancer, together with new concepts and technologies.

Abbreviations: $\mathrm{AMACR}, \alpha$-methylacyl coenzyme $\mathrm{A}$ racemase; $A R$, androgen receptor; GSTP1, glutathione $S$ transferase; IFN, interferon; IL-6, interleukin 6; KLF, Kruppel-like factor; MAPK, mitogen activated protein kinase; P13K-Akt, phosphatidylinositol 3'-kinase-protein kinase B; PIN, prostate intraepithelial neoplasia; PSA, prostate specific antigen; PTEN, phosphatase and tensin homologue; $\mathrm{Rb}$, retinoblastoma; STAT, signal transducer and activator of transcription; VDR, vitamin $D$ receptor 


\section{HEREDITARY PROSTATE CANCER}

Prostate cancer can be divided epidemiologically into hereditary and sporadic forms, ${ }^{3}$ but it is not possible to distinguish these two groups at a molecular level. Highly penetrant inherited genes conferring the prostate cancer phenotype have not been identified.

Linkage studies using genetic markers to search for chromosomal regions that show excessive sharing of inherited alleles in cancer affected families have been helpful in identifying important cancer susceptibility genes in other cancers. However, similar studies using families prone to prostate cancer have not yielded the same success.

"The failure to identify highly penetrant genes in hereditary prostate cancer may result from the fact that multiple genes with a small to moderate effect are involved in hereditary prostate carcinogenesis"

Although possible inherited prostate cancer susceptibility genes have been identified such as the ELAC2, RNASEL, MSR1, NSB1, and CHEK2 genes in some families (table 1), the proportion of cases of hereditary prostate cancer attributable to germline mutations in these loci is small. Many studies have not supported the role of these genes in hereditary prostate cancer. Mutations of these candidate genes have also been identified in sporadic prostate cancer. Because prostate cancer is a common cancer, it may be difficult to distinguish clustering of sporadic prostate cancer within families from true hereditary prostate cancer. This difficulty may have hindered research into hereditary prostate cancer to date. Alternatively, the failure to identify highly penetrant genes in hereditary prostate cancer may result from the fact that multiple genes with a small to moderate effect are involved in hereditary prostate carcinogenesis. The risk of disease in the presence of a susceptibility gene might be substantially increased only in the appropriate genetic, dietary, and environmental background. ${ }^{4}$ We will briefly outline the most important hereditary prostate cancer susceptibility genes identified to date.

\section{ELAC2}

ELAC2 was the first possible hereditary prostate cancer gene to be identified. The function of ELAC2 is not definitively known and it has been proposed as a metal dependent hydrolase. An association of ELAC2 genotypes with familial prostate cancer has been reported. ${ }^{5}$ However, multiple large subsequent studies have not provided confirmatory evidence of this association. ${ }^{67}$

Overall, it appears that if ELAC2 plays a role in prostate cancer it is a relatively minor role.

\section{Host response to infection genes RNASEL}

RNASEL is a ribonuclease that degrades viral and cellular RNA and can produce apoptosis on viral infection. Mutations in the RNASEL gene have been identified in familial and sporadic prostate cancer in many studies, ${ }^{8-12}$ although other studies have not supported these findings. ${ }^{13} 14$

Overall, there is strong support for the notion that RNASEL is the most important hereditary prostate cancer gene identified to date.

\section{MSR 1}

MSRl encodes a macrophage scavenger receptor responsible for cellular uptake of molecules, including bacterial cell wall products. The importance of MSRl as a prostate cancer susceptibility gene in hereditary prostate cancer is controversial. Germline MSRl mutations have been linked to prostate cancer in some families with prostate cancer and in sporadic prostate cancer. ${ }^{15}{ }^{16}$ However, a recent report, which investigated 163 families with familial prostate cancer, did not provide confirmatory evidence of the role of MSRl in familial prostate cancer. ${ }^{17}$

Mutations of these host response to infection genes may increase the risk of prostate cancer by predisposing to chronic inflammation as a result of failure of viral RNA and bacterial degradation. There is accumulating knowledge supporting the role of inflammation in prostate cancer, which we will refer to again later in the article.

\section{Cell cycle checkpoint genes NBS 1}

The rare human genetic disorder, Nijmegen breakage syndrome, is characterised by radiosensitivity, immunodeficiency, chromosomal instability, and an increased risk for cancer of the lymphatic system. The NBSl gene, which is involved in this human genetic disorder, encodes a protein, nibrin, involved in the processing/repair of DNA double strand breaks and in cell cycle checkpoints. ${ }^{18}$ Mutations in the gene for the Nijmegen breakage syndrome (NBS1) have been identified in both sporadic and familial cases of prostate cancer and are associated with a small increased risk of prostate cancer. ${ }^{19}$

\section{CHEK2}

The CHEK2 gene is an upstream regulator of p53 in the DNA damage signalling pathway. CHEK2 mutations have been identified in both sporadic and familial cases of prostate cancer and are associated with a small increased risk of prostate cancer. ${ }^{2021}$

NBS1 and CHEK2 genes have only recently been identified as possible prostate cancer susceptibility genes. ELAC2 was the first hereditary prostate cancer susceptibility gene identified and subsequent studies have not provided confirmatory evidence of its role in prostate cancer. Therefore, it is not possible to comment on the importance of these two genes in hereditary prostate cancer until additional confirmatory studies have been performed.

The study of hereditary prostate cancer genes is in its infancy and the challenge for the future will be to detect genes with small to moderate effects. Advances in statistical

Table 1 Hereditary prostate cancer genes

\begin{tabular}{|c|c|c|c|}
\hline Gene & Chromosomal locus & Putative function & Status in prostate cancer \\
\hline ELAC2 & $17 p$ & Metal dependent hydrolase & Unknown \\
\hline RNASEL & $1 q$ & $\begin{array}{l}\text { Ribonuclease that degrades viral and cellular RNA and can produce } \\
\text { apoptosis on viral infection }\end{array}$ & Deleted \\
\hline MSR1 & $8 p$ & $\begin{array}{l}\text { Encodes a macrophage scavenger receptor responsible for cellular } \\
\text { uptake of molecules, including bacterial cell wall products }\end{array}$ & Deleted \\
\hline NBSI & $5 p$ & $\begin{array}{l}\text { Encodes a protein, nibrin, involved in the processing/repair of DNA } \\
\text { double strand breaks and in cell cycle checkpoints }\end{array}$ & Deleted \\
\hline CHEK2 & $22 q$ & Upstream regulator of p53 in the DNA damage signalling pathway & Deleted \\
\hline
\end{tabular}


methods to amplify signals from susceptibility genes in the presence of heterogeneous factors are required to decipher the genetics and molecular pathology of hereditary prostate cancer.

\section{SPORADIC PROSTATE CANCER}

Most prostate cancers are sporadic. In our discussion of the molecular pathology of sporadic prostate cancer we will discuss the evidence to date under the following categories: polymorphisms associated with increased prostate cancer risk, somatic genetic changes, and factors involved in the progression of prostate cancer, such as the androgen receptor, growth factors, and invasion and metastasis genes. We will discuss separately recent findings of gene overexpression and underexpression by microarray technology. The application of the field of proteomics to the study of prostate cancer and current theories regarding the role of inflammation in prostate cancer will also be discussed.

\section{Polymorphisms associated with increased prostate cancer risk (table 2)}

A polymorphism is a genetic variant that appears in at least $1 \%$ of the population. These common genetic polymorphisms probably have small relative risks, yet large population attributable risks because of their high frequencies.

\section{TLR4}

TLR4 encodes a receptor that is a central player in the signalling pathways of the innate immune response to infection by Gram negative bacteria. A TLR4 sequence polymorphism is associated with a small increased risk of prostate cancer. ${ }^{22}$ This is in keeping with the current hypothesis of inflammation having a role in prostate carcinogenesis. We will discuss the current hypothesis of the role of inflammation in prostate cancer later in the article.

\section{CDKN1B (p27)}

The loss of cell cycle control is thought to be an important mechanism in the promotion of carcinogenesis. CDKNIB (p27) belongs to the Cip/Kip family and functions as an important cell cycle gatekeeper.

A recent study has revealed a significant association between a single nucleotide polymorphism of CDKN1B (p27) and prostate cancer. ${ }^{23}$ There is also an association between CDKN1B (p27) and another Cip/Kip family member, CDKNIA (p21), and advanced prostate cancer. ${ }^{24}$

\section{Androgen receptor (AR)}

Growth of prostate cells depends on androgens. Genes that encode products that play a role in inducing androgen stimulation of the prostate gland are very important. The

\begin{tabular}{|c|c|c|}
\hline Gene & $\begin{array}{l}\text { Chromosomal } \\
\text { locus }\end{array}$ & Function \\
\hline TLR4 & $9 q$ & $\begin{array}{l}\text { Encodes a receptor that is a central } \\
\text { player in the signalling pathways of the } \\
\text { innate immune response to infection by } \\
\text { Gram negative bacteria }\end{array}$ \\
\hline $\begin{array}{l}\text { CDKNIB } \\
\text { (p27) }\end{array}$ & $12 p$ & $\begin{array}{l}\text { Belongs to the Cip/Kip family and } \\
\text { functions as an important cell cycle } \\
\text { gatekeeper }\end{array}$ \\
\hline AR & $X q$ & $\begin{array}{l}\text { May cause activation of androgen } \\
\text { dependent genes }\end{array}$ \\
\hline CYP17 & $10 q$ & $\begin{array}{l}\text { Enzyme responsible for the biosynthesis } \\
\text { of testosterone. }\end{array}$ \\
\hline SRD5A2 & $2 p$ & $\begin{array}{l}\text { Converts testosterone to the more poten } \\
\text { dihydrotestosterone }\end{array}$ \\
\hline
\end{tabular}

androgen receptor (AR) is currently a therapeutic target for the treatment of prostate cancer. Other genes involved in androgen stimulation of the prostate such as SRD5A2 and CYP17 also hold potential as future therapeutic targets.

The AR contains polymorphic polyglutamine $(\mathrm{CAG})_{\mathrm{n}}$ trinucleotide repeats. It has been reported in the past that shortening of these repeats is associated with increased prostate cancer risk. ${ }^{25}$

Short CAG length has also been correlated with high grade, high stage, metastatic, and fatal prostate cancers. A hypothesis that has been proposed for the influence of the short CAG repeat on prostate carcinogenesis is that because of its role in AR function it causes an increase in activation of androgen dependent genes. ${ }^{26}$

Other groups have not identified CAG repeats as a risk factor for prostate cancer and a recent study and an epidemiological review article have shown that this risk factor is less important than thought previously. ${ }^{27} 28$

\section{CYP17}

CYP17 encodes cytochrome P-450c17 $\alpha$, an enzyme responsible for the biosynthesis of testosterone. A variant CYP17 allele is associated with both hereditary and sporadic prostate cancer. ${ }^{29}$ This allele is hypothesised to increase the rate of gene transcription, increase androgen production, and thereby increase the risk of prostate cancer. ${ }^{30}$

\section{SRD5A2}

SRD5A2 encodes the predominant isozyme of $5 \alpha$-reductase in the prostate, an enzyme that converts testosterone to the more potent dihydrotestosterone. The alleles that encode enzymes with increased activity have been associated with an increased risk of prostate cancer and with a poor prognosis for men with prostate cancer. ${ }^{31} 32$

\section{Polymorphisms associated with advanced sporadic prostate cancer (table 3) \\ Vitamin D receptor}

Physiological concentrations of vitamin D promote the differentiation and growth arrest of prostate cancer cells in vitro. ${ }^{33}$ The precise mechanism through which vitamin $\mathrm{D}$ mediates this effect is unknown, although it is probably through its effect on cell growth proteins. Allelic differences in the vitamin D receptor (VDR) gene result in variation in VDR activity. ${ }^{34}$ VDR alleles have been significantly associated with prostate cancer and this association was stronger with advanced prostate cancers. ${ }^{35}$ As discussed previously, polymorphisms in CDKN1A (p2 $1^{\mathrm{cip}}$ ) and CDKN1B (p27 $7^{\mathrm{kip}}$ ) are associated with advanced prostate cancer. ${ }^{24}$ In addition, polymorphic variants of several other genes have been proposed as possible contributors to the risk of prostate cancer. ${ }^{36}$

Table 3 Polymorphisms associated with advanced prostate cancer risk

\begin{tabular}{|c|c|c|}
\hline Gene & $\begin{array}{l}\text { Chromosomal } \\
\text { locus }\end{array}$ & Function \\
\hline $\begin{array}{l}\text { Vitamin D } \\
\text { receptor }\end{array}$ & $13 q$ & $\begin{array}{l}\text { Promotes the differentiation and } \\
\text { growth arrest of prostate cancer } \\
\text { cells in vitro }\end{array}$ \\
\hline CDKN1A (p21) & $6 p$ & $\begin{array}{l}\text { Belong to the Cip/Kip family and } \\
\text { functions as an important cell cycle } \\
\text { gatekeeper }\end{array}$ \\
\hline CDKN1B (p27) & $12 p$ & \\
\hline
\end{tabular}




\section{Somatic genetic changes}

The number of genetic loci involved in prostate carcinogenesis is large and the mechanisms are complex and not fully understood. Table 4 lists the most commonly reported chromosomal abnormalities in sporadic prostate cancer, together with the putative genes involved at these chromosomal sites. ${ }^{37} 38$

Although these are the most common areas of chromosomal loss and gain, prostate carcinogenesis is complex and multiple genes from other chromosomal loci are also thought to be involved.

Tumour suppressor genes and loss of heterozygosity Tumour suppressor genes are probably involved in the prostate carcinogenesis pathway. Loss of tumour suppressor genes was initially proposed to occur via loss of function of two alleles (the "two hit hypothesis") by mutation or deletion. ${ }^{48}$ This model has been revised to include epigenetic modification by (a) inactivation of one or both alleles by DNA methylation of $\mathrm{CpG}$ sites in gene promoters, (b) function heritably downregulated, or (c) otherwise compromised in a clonal fashion. ${ }^{49}$ The change can be by mutation, methylation of the promoter, or by some other modification of the protein product, and must be coupled with evidence that the normal (wild-type) gene does suppress growth of tumour cells. ${ }^{50}$

\section{Glutathione S-transferase gene}

The glutathione S-transferase (GSTP1) gene is emerging as one of the most important tumour suppressor genes in prostate cancer. GSTP1 can detoxify environmental electrophilic carcinogens and oxidants and may play a genome caretaker role by preventing oxidant and electrophilic DNA damage. ${ }^{51}$ GSTPl has been shown to be inactivated by hypermethylation of the promoter region in prostate tumours. ${ }^{52}{ }^{53}$ Hypermethylation of GSTPl is the most common $(>90 \%)$ reported epigenetic alteration in prostate cancer. It occurs early in cancer progression and is a promising marker for detecting organ confined disease. The quantitation of GSTPl hypermethylation can accurately detect the presence of cancer even in small, limited tissue samples. It is a promising diagnostic marker that could possibly be used as an adjunct to tissue biopsy as part of prostate cancer screening. ${ }^{54}$

Aberrant DNA methylation patterns may be the earliest somatic genome changes in prostate cancer. A recent study found that $\mathrm{CpG}$ islands were hypermethylated in $>85 \%$ of prostate cancers and cancer cell lines but not in normal prostate cells and tissues. CpG island hypermethylation patterns in prostate cancer metastases were very similar to the primary prostate cancers and tended to show greater differences between cases than between anatomical sites of metastasis. ${ }^{55}$

\section{PTEN}

PTEN (phosphatase and tensin homologue) is an important tumour suppressor gene in prostate cancer and influences the concentrations of CDKN1B (p27) another important tumour suppressor gene. The PTEN gene encodes a phosphatase active against both protein and lipid substrates and is a common target for somatic alteration during the progression of prostate cancer. ${ }^{56}{ }^{57}$ PTEN is present in normal epithelial cells and in cells in prostatic intraepithelial neoplasia (PIN). In prostate cancers, concentrations of PTEN are often reduced, particularly in cancers of high grade or stage. In prostate cancers that do contain PTEN, there is considerable heterogeneity in concentrations, with regions devoid of PTEN being described. ${ }^{44}$ The mechanism by which PTEN might act as a tumour suppressor gene in the prostate may involve inhibition of the phosphatidylinositol 3'-kinase-protein kinase B (P13K-Akt) signalling pathway, which is essential for cell cycle progression and cell survival. ${ }^{58}$

\section{CDKN1B (p27)}

CDKN1B (p27) is an important tumour suppressor gene in prostate cancer. Reduced concentrations of p27, a cyclin dependent kinase inhibitor encoded by the CDKNIB gene, are common in prostate cancers, particularly in those with a poor prognosis..$^{50}$ The somatic loss of DNA sequences at 12 p12-3, encompassing CDKN1B, has been described in $23 \%$ of localised prostate cancers, $30 \%$ of prostate cancer metastases in regional lymph nodes, and $47 \%$ of distant prostate cancer metastases. ${ }^{61}$ Concentrations of p27 are suppressed by the P13K-Akt signalling pathway. ${ }^{58}$ By inhibiting P13K-Akt, PTEN can increase the concentration of CDKN1B mRNA and p27 protein. ${ }^{62}$ For this reason, low p27 concentrations may be as much a result of the loss of PTEN function as of CDKNIB alterations.

\section{NKX3.1}

Loss of $8 \mathrm{p}$ appears to be an early event in prostate cancer and the most promising candidate tumour suppressor gene at this site is NKX3.1, which encodes a prostate specific homeobox gene that is probably essential for normal prostate development. NKX3.1 binds to DNA and represses expression of the PSA gene. ${ }^{63}$ Loss of NKX3.1 expression appears to be related to the progression of prostate cancer. One study found that NKX3.1 was absent in $20 \%$ of PIN lesions, $6 \%$ of low stage prostate cancers, $22 \%$ of high stage prostate cancers, $34 \%$ of androgen independent prostate cancers, and $78 \%$ of prostate cancer metastases. ${ }^{42}$ The loss of this gene is of particular interest because when present it represses expression of the PSA gene, and the loss of NKX3.1 may be involved in the increasing concentrations of PSA seen with prostate cancer progression.

Table 4 The most commonly described areas of chromosomal loss and gain in prostate cancer

\begin{tabular}{llllr}
\hline Chromosome locus & Putative genes & Normal function of gene & Status of gene in prostate cancer Ref \\
\hline $7 p$ & EGFR & Growth factor & Amplified & 39 \\
$7 q$ & CAV 1 & $\begin{array}{l}\text { Structural protein of caveolae membranes in fibroblasts } \\
\text { and endothelia }\end{array}$ & Amplified \\
$8 p$ & Encodes a macrophage scavenger receptor responsible & Deleted & 40 \\
& for cellular uptake of molecules including bacterial cell & & 41 \\
$8 p$ & wall products & Deleted & 42 \\
$8 q$ & Tumour suppressor gene & Amplified & 43 \\
$10 q$ & TKX3-1 & Mutated & 44 \\
$13 q$ & Transcriptional activator & Deleted & 45 \\
$16 q$ & TTEN & Tumour suppressor gene & Deleted & 46 \\
Xq & Rb & Tumour suppressor gene & Amplified & 47 \\
\hline EGFR, epidermal growth factor receptor; PTEN, phosphatase and tensin homologue; Rb, retinoblastoma. & & \\
\hline
\end{tabular}




\section{KLF6}

Kruppel-like factors (KLFs) comprise a group of transcription factors that appear to be involved in different biological processes including carcinogenesis. Important genetic alterations of KLF6 have been reported, including deletions and loss of expression in a minority of high grade prostate cancers. ${ }^{64} 65$

KLF6 and NKX3.1 have not been reported as frequently as the tumour suppressor genes previously discussed and have been identified because of the fact that they are within areas of frequent allelic loss in prostate tumours.

\section{Retinoblastoma}

Retinoblastoma $(\mathrm{Rb})$ has been reported to be an important tumour suppressor gene in many human cancers, and prostate cancer is no exception. The disruption of the normal $\mathrm{Rb}$ regulatory pathway is associated with the pathogenesis of many human cancers. The $\mathrm{Rb}$ gene plays an important role in the Gl phase of the cell cycle. The Rb protein binds tightly to the E2F family of transcription factors. When phosphorylated, the $\mathrm{Rb}$ protein releases the E2F proteins, causing transcriptional activation of a variety of genes involved in cell growth. ${ }^{45}{ }^{66}{ }^{67}$ Inactivation of $\mathrm{Rb}$ appears to be important in neoplastic transformation, because expression of wild-type $\mathrm{Rb}$ in $\mathrm{Rb}$ negative prostate cancer lines results in loss of tumorigenicity. ${ }^{68}$ The predominant mechanism of $\mathrm{Rb}$ inactivation involves allelic loss or mutation, but decreased transcription of $\mathrm{Rb}$ has also been reported. ${ }^{69} 70$

\section{p53}

Mutations in p53 are common in human neoplasms, but there is only a low frequency of mutation of this gene in prostate cancer. However p53 has an important role in prostate cancer progression because abnormal p53 expression is associated with bone metastases and the development of androgen independent disease. Abnormal p53 expression correlates with high histological grade, high stage, and clinical disease progression.

The p53 tumour suppressor gene product restricts entry into the synthetic phase of the cell cycle and promotes apoptosis in cells that are disorganised or have damaged DNA. Loss of normal p53 function results in uncontrolled cell growth. ${ }^{71}$

The analysis of p53 expression can be difficult. The mutated p53 gene product has a longer half life, thus rendering it detectable by immunohistochemistry. However, sensitive immunohistochemical techniques may detect overexpressed normal p53. Therefore, it is more reliable to detect mutations in p53 by molecular techniques. Abnormal p53 expression is correlated with reduced survival after radical prostatectomy. ${ }^{72}$

\section{Oncogenes}

c-myc and bcl-2 are well known and important oncogenes not only in prostate cancer but in many human cancers.

\section{c-myc}

Several studies have demonstrated increased myc expression in prostate cancer and a significant correlation of myc overexpression with Gleason grade. The myc oncogenes are members of the basic helix-loop-helix-leucine zipper (bHLHZ) family of transcription factors. Myc proteins act as transcriptional activators or repressors through dimerisation or with other bHLHZ family members. ${ }^{43} 7073-75$

\section{bcl-2}

The bcl-2 family of genes are commonly expressed in primary and metastatic prostate cancers. bcl-2 is not expressed in the normal prostate. Proteins of the bcl-2 family play a crucial role in the regulation of apotosis and the bcl-2 gene inhibits programmed cell death. ${ }^{76-78}$ bcl-2 has also been implicated in the development of androgen independent prostate cancer because of its increased expression in androgen independent cancers in the advanced stages of disease..$^{70}$

Other oncogenes have only recently been recognised, but may emerge as novel targets for molecular genetic intervention, or through modified expression may allow accurate prediction of the way in which a tumour is likely to progress.

\section{c-Kit/tyrosine kinase receptor}

c-Kit (tr-Kit) is a strong activator of the Src family tyrosine kinases. In a recent study it has been reported that human trKit mRNA and protein are expressed in prostatic cancer cells. This study also describes for the first time the existence of a truncated c-Kit protein in primary tumours and shows a correlation between tr-Kit expression and activation of the Src pathway in the advanced stages of the disease. ${ }^{81}$

\section{STAT5}

A signal transducer and activator of transcription, 5 (STAT5) has been identified as a crucial survival factor for prostate cancer cells. ${ }^{82}$ Activation of STAT5 is also associated with high histological grade of prostate cancer. ${ }^{83}$

\section{Telomerase and telomere shortening}

Telomere length has been found to be strikingly shorter in prostate cancer, including PIN, than in normal prostate. Telomeres stabilise and protect the ends of chromosomes, but shorten because of cell division and/or oxidative damage. Critically short telomeres, in the setting of abrogated DNA damage checkpoints, have been shown to cause chromosomal instability, leading to an increase in cancer incidence as a result of chromosome fusions, subsequent breakage, and rearrangement. In normal cells, successive cycles of cellular replication result in progressive loss of telomeric sequences. Normal cells sense very short telomeres as evidence of DNA damage and exit the cell cycle. ${ }^{84}$ Telomerase is an enzyme that maintains telomere length by adding repetitive telomeric sequences to chromosome ends. Telomerase activity is present in most prostate cancers and not in normal prostate epithelium. ${ }^{85} 86$

\section{Androgen receptor (AR)}

The AR plays a crucial role in prostate cancer. AR blockade can delay the progression of prostate cancer and is used to treat patients unsuitable for radical surgery or with cancer that has spread beyond the prostate. It has been studied extensively in prostate cancer because androgens are required for the development of both the normal prostate and prostate cancer. Initially, most prostate cancers are sensitive to androgen deprivation.

However, in patients with advanced disease, most tumours progress to an androgen independent state with proliferation of cells that do not require androgens for growth.

The mechanism of acquired androgen insensitivity is unknown and has been the subject of much research, because androgen insensitive prostate cancers can no longer be treated with endocrine therapy.

Mutations, amplifications, and deletions of the AR gene and structural change in the AR protein have been postulated to cause androgen insensitivity. ${ }^{47}{ }^{87-91}$

\section{"In patients with advanced disease, most tumours progress to an androgen independent state with prolifera- tion of cells that do not require androgens for growth"}

In an analysis of 44 mutant ARs from prostate cancers, seven had loss of function, three maintained wild-type 
function, 14 demonstrated partial function, and 20 displayed a gain in function. ${ }^{92}$

However, structural change of the AR has only been identified in a minority of androgen insensitive prostate cancers, so that other factors must also be involved in this phenomenon.

Growth factor stimulation may sensitise the AR transcriptional complex to subphysiological concentrations of androgen. ${ }^{93}$ We will refer to this topic once again when we discuss the role of growth factors in prostate cancer.

\section{Growth factors}

Growth factors are important in the normal regulation of prostate development and growth. However, the inappropriate expression of members of the growth factor families has been associated with prostate cancer progression. ${ }^{94}$

\section{Interleukin 6}

Interleukin 6 (IL-6) modulates cell growth and apoptosis. It is a multifunctional cytokine that activates the STAT and/or mitogen activated protein kinase (MAPK) signalling pathways. IL- 6 values are raised in tissues and sera from patients with prostate cancer and IL-6 receptor expression has been detected in prostate cancer cell lines and clinical specimens.

Chronic exposure of prostate cancer cells to IL-6 has been found to facilitate tumour growth in vivo by abolishing growth control by the Rb protein and activation of the MAPK signalling pathway. ${ }^{95}$ Il-6 has also been shown to play a role in the interaction between epithelial and stromal cells in prostate cancer. ${ }^{96}$

Epidermal, transforming, vascular endothelial, and insulin growth factors

Many of these growth factor receptors engage the Ras-MAPK pathway as part of their signalling activities. These growth factors have been shown to be associated with invasion and metastasis of prostate cancer. ${ }^{93}$ 97-99 Transforming growth factor $\beta$ and vascular endothelial growth factor can also cause prostate cancer progression by acting as angiogenic factors increasing microvessel density around the cancer. ${ }^{100}{ }^{101}$ There is evidence that chronic activation of endogenous c-Ras by autocrine and paracrine growth factor stimulation sensitises the AR transcriptional complex to subphysiological concentrations of androgen. Progression to hormone refractory disease is often correlated with overexpression of growth factors and receptors capable of establishing autocrine and/or paracrine growth stimulatory loops. ${ }^{93}$ Chemotherapy with the aim of interrupting these loops may be a possibility for the treatment of prostate cancer in the future.

\section{Growth factor receptors}

Growth factor receptors have been recognised as important oncogenes in many cancers, particularly the growth factor cerb 2 (Her-2 neu).

\section{C-erb 2 (Her-2 neu)}

There is some controversy over the role of c-erb 2 (Her-2 neu) in prostate cancer.

C-erb 2 belongs to the epidermal growth factor receptor family. Some fluorescence in situ hybridisation studies of primary prostate cancer specimens have suggested that c-erb 2 gene amplification and neu overexpression are significantly correlated with DNA content, advanced grade, and advanced stage. ${ }^{102-104}$ However, large studies using fluorescence in situ hybridisation (339 cases) and comparative in situ hybridisation (126 cases) showed that c-erb 2 is not amplified in prostate cancer. ${ }^{105} 106$

"There is some controversy over the role of c-erb 2 (Her-2 neu) in prostate cancer"
Immunohistochemical studies have given rise to conflicting results because of the use of different methodologies and different antibodies. Some studies report c-erb 2 (Her-2 neu) overexpression in prostate cancer and some suggest that expression increases as prostate cancer progresses to androgen independence. ${ }^{107} 108$ Other studies have not identified Her-2 neu amplification or overexpression in prostate cancer. ${ }^{109-111}$ In summary, when evaluated scientifically the research to date shows that the c-erb 2 (Her-2 neu) gene is not amplified in prostate cancer. Whether c-erb 2 (Her-2 neu) is overexpressed in prostate cancer remains controversial, but studies with immunostaining and with quantitative reverse transcription polymerase chain reaction have shown that the expression of c-erb 2 is much lower than in-for example, breast carcinomas, in which c-erb 2 (Her-2 neu) amplification and overexpression is common. ${ }^{112}$ Chemotherapy currently targeted towards c-erb 2 overexpression in breast cancer is unlikely to have similar clinical application in prostate cancer.

\section{Fas/Fas ligand}

Fas is a type I membrane receptor of the tumour necrosis factor/nerve growth factor family. On binding to Fas ligand, a type II transmembrane protein, the Fas-Fas ligand complex induces apoptosis in target cells. Dysregulation of Fas and Fas ligand mediated apoptosis is thought to be involved in prostate tumorigenesis. The Fas-Fas ligand complex has been found to be raised in prostatic intraepithelial neoplasia and prostatic adenocarcinoma. ${ }^{113}$

c-met

Hepatocyte growth factor and its receptor, the c-met protooncogene product (c-met), have been implicated in embryogenesis, tissue reorganisation, and tumour progression.

The c-met protein has been detected in a substantial number of prostate cancers and has been found more often in metastatic growths of prostate carcinoma and in androgen insensitive prostate cancer cell lines. There is also evidence that c-met (hepatocyte growth factor) enhances the invasive potential of prostate cancer cells. ${ }^{114}$ High c-met receptor expression has also been identified in prostate cancer metastasis to bone. ${ }^{115} 116$

\section{Invasion and metastasis suppressing genes}

For cancer cells to spread to distant sites they must invade the stroma, penetrate the vasculature, implant at distant sites, and be able to survive there. Changes of adhesion to the substratum are crucial for tumour cell invasion and distant metastasis. Several genes encoding proteins involved in invasion and metastasis in prostate cancer have been identified.

\section{E-cadherins}

The cadherins are membrane glycoproteins that play an important role in cellular differentiation by mediating cellcell recognition and adhesion. Reduction of E-cadherin expression is a common occurrence in prostate cancer, and has been reported to correlate with tumour grade, stage, and survival. ${ }^{46}{ }^{117-119}$ However, the degree of E-cadherin expression in prostate cancer remains controversial. Normal expression of E-cadherin was found in most prostate carcinoma cases examined in an immunohistochemical study that systematically evaluated E-cadherin expression in a broad range of formalin fixed prostate tissues. ${ }^{120}$

\section{Integrins}

Normal basal epithelial cells in the human prostate express integrins but their expression is abnormal or absent in most prostate cancers. ${ }^{121-123}$ 


\section{C-CAM}

The C-CAM cell adhesion molecule is expressed on the surface of normal prostate epithelium but is absent in most prostate cancers. ${ }^{124}$ Loss of C-CAMl expression occurs early in the development of prostate cancer, suggesting that C-CAMl may help maintain the differentiated state of the prostate epithelium. Reintroduction of C-CAMl into cancer cells can reverse their cancerous growth. ${ }^{125}$

\section{$\mathrm{KAIl} / \mathrm{CD} 82$}

Metastasis suppressor genes are defined as genes that do not affect the growth of primary tumour cells but can inhibit development of distant metastases. ${ }^{126}$ The cancer metastasis suppressor KAIl/CD82 belongs to the tetraspanin superfamily and inversely correlates with the metastatic potential of a variety of cancers, including prostate cancers. CD82 expression is reduced or absent in most primary prostate cancers and in more than $90 \%$ of metastatic prostate cancers. ${ }^{127}{ }^{128}$ It is thought that the mechanism of KAIl/ CD82 mediated metastasis suppression involves a cell surface protein physically associated with KAIl/CD82, named KASP. ${ }^{129}$

\section{CD44}

CD44 is another metastasis suppressor gene for prostatic cancer and CD44 expression is inversely correlated with histological grade, ploidy, and distant metastases. ${ }^{130} 131$

\section{Other metastasis suppressor genes}

Additional candidate metastasis suppressor genes that have been identified for prostate cancer are NME23, mapsin, BRMSI, KISSI, and MAP2K4. ${ }^{126}$

\section{Clinical implications}

The identification of invasion and metastasis suppression genes has potential clinical applications. Prostate cancers with loss of these genes may have a potentially metastatic phenotype and may require more aggressive treatment in contrast to cancers that have retained expression.

\section{"The identification of invasion and metastasis suppression genes has potential clinical applications"}

In our opinion, the most promising genes that could be used as specific targets for the detection, diagnosis, and treatment of prostate cancer include the tumour suppressor genes GSTP1, NKX3.1, PTEN, and p27. NKX3.1, PTEN, and p27 also involve growth factor signalling pathways, which have potential for molecular genetic intervention. Genes that play a role in inducing androgen stimulation of the prostate gland such as AR, SRD5A2, and CYP17 are also potential targets for gene therapy in the future.

\section{GENE OVEREXPRESSION AND UNDEREXPRESSION IN PROSTATE CANCER DETECTED BY CDNA MICROARRAYS}

Given the difficulty in finding inherited susceptibility genes, the evidence that prostate cancer is probably caused by multiple genes with complex interactions continues to grow. Many studies have concentrated on one gene at a time. Future studies may need to consider the simultaneous effects of multiple genes. This will involve larger sample sizes, particularly if the effect of each gene is small, and microarray technology is suited to examining multiple genes simultaneously. Sophisticated statistical models using DNA and cDNA microarrays allow the analysis of large numbers of genes and gene expression at a high resolution. We will discuss those genes that, in our opinion, are the most important overexpressed and underexpressed genes in prostate cancer, and which have been identified by microarrays.

\section{Gene overexpression}

Hepsin

The hepsin gene product is a membrane bound serine protease present in most tissues but at its highest concentrations in liver tissue. This protein is thought to have an important role in cell growth. The hepsin gene product was found to be overexpressed in PIN and in prostate cancer using cDNA expression arrays. Using both microarrays of cDNA and tissue microarrays, the degree of hepsin expression distinguished prostate neoplasms of clinically stratified prostate cancer. ${ }^{132}$ Expression of the hepsin protein in prostate cancer correlated inversely with patient prognosis. ${ }^{133}$

Identification of features that can accurately predict the behaviour of prostate cancer within a specific patient is a major challenge. Gleason grading is based on morphological features and is a powerful prognostic indicator, although there can be difficulties with interobserver reproducibility. In addition, prostate carcinomas that are morphologically indistinguishable and discovered incidentally can behave in a clinically indolent fashion or aggressively. The identification of genes by the new microarray technology that correlate with patient prognosis is an exciting development with potential clinical application.

\section{$\alpha$-Methylacyl coenzyme $A$ racemase}

The $\alpha$-methylacyl coenzyme A racemase (AMACR) gene is involved in the $\beta$ oxidation of branched chain fatty acids and fatty acid derivatives. ${ }^{134}$ The enzyme encoded by the AMACR gene plays a crucial role in peroxisomal $\beta$ oxidation of branched chain fatty acid molecules. AMACR positivity in prostate cancer could have important epidemiological and preventive implications, because the main sources of branched chain fatty acids are dairy products and beef, the consumption of which has been associated with an increased risk for prostate cancer in multiple studies. ${ }^{135}$ Both untreated metastases and hormone refractory prostate cancers have been found to be strongly positive for AMACR. ${ }^{136}$ AMACR expression has also been found to be a marker of tumour differentiation. ${ }^{137}$ In diagnostic histopathology, the AMACR marker has the ability to support a diagnosis of malignancy in prostate needle biopsies. Although it has limitations with respect to sensitivity and specificity, AMACR will no doubt become a standard adjunctive stain used by pathologists seeking to reach a definitive diagnosis in prostate biopsies considered to be atypical but not diagnostic of malignancy on haematoxylin and eosin stained sections alone. ${ }^{138}$

\section{PIM 1}

PIMl encodes a protein kinase upregulated in prostate cancer. The PIMl gene product was also found to be overexpressed in PIN and in prostate cancer using cDNA expression arrays. The degree of PIMl expression distinguished clinically stratified prostate neoplasms using microarrays of cDNA and tissue microarrays. Decreased expression of PIMl kinase in prostate cancer correlated significantly with measures of poor patient outcome, to an even greater extent than hepsin. ${ }^{133}$

A remarkably similar cotranscriptional regulation or gene amplification of PIMl and the oncogene c-myc (previously discussed) has been identified, possibly mediating a synergistic oncogenic effect in prostate cancer.

\section{MTA 1}

Expression of the metastasis associated protein 1 (MTAl) has previously been found to be associated with progression to the metastatic state in various cancers. A recent study identified an association of MTAl expression and prostate 
cancer progression. Metastatic prostate cancer demonstrated significantly higher mean MTAl protein expression intensity compared with clinically localised prostate cancer or benign prostate tissue. ${ }^{139}$

\section{$\mathrm{EZH} 2$}

EZH2 is a developmental regulatory gene that is a transcriptional repressor and is found in higher concentrations in metastatic prostate cancers than in primary tumours. ${ }^{140}$ Other genes such as CSEIL, ZNF217, MYBL2, and STK15 have also been found to be overexpressed in prostate cancer. ${ }^{141}{ }^{142}$

\section{Gene underexpression}

Gene expression profiling using microarray technology and other techniques has also demonstrated genes that are downregulated or underexpressed in prostate cancer. In our opinion, two of the most important groups of genes that are down regulated are the interferons and annexins.

\section{Interferons and interferon inducible molecules}

In a study that compared gene expression profiles of tumorigenic versus non-tumorigenic human prostatic epithelium a large proportion of the downregulated genes encoded interferon (IFN) inducible molecules. IFN was also shown to inhibit tumorigenic human prostatic epithelium cell proliferation and colony formation in vitro and inhibit tumour growth in xenografts in vivo. ${ }^{143}$

IFNs are mainly thought to play an indirect immunosurveillance role that is not specific for prostate cancer. IFNs are thought to have an antiproliferative effect and can affect the expression of CDKN1A (p21), which belongs to the Cip/Kip family. This finding has possible clinical applications and suggests IFN inducible molecules as potential therapeutic targets for the treatment of prostate cancer.

\section{Annexins}

Annexins play important roles in maintaining calcium homeostasis and regulating the cytoskeleton and cell motility. Downregulation of annexins has been identified in prostate cancers using cDNA microarrays. Annexins have also been found to be significantly downregulated in prostate cancer cell lines, suggesting that loss of expression may contribute to prostate cancer development and progression. ${ }^{144} 145$

\section{EPHB2}

EPHB2 is a receptor tyrosine kinase gene and is thought to have an essential role in cell migration and maintenance of normal tissue architecture. It has been reported to be overexpressed in gastric cancer; however, in a study using combined nonsense mediated RNA decay microarrays and array based comparative genomic hybridisation, mutational inactivation of EPHB2 was identified in a small fraction of prostate carcinomas. The identification of this possible tumour suppressor gene in prostate cancer is an example of how microarray technology is a powerful new molecular pathology tool. ${ }^{146}$

\section{Other genes}

Decreased expression of the tumour suppressor gene PTEN and the adhesion gene (E-cadherin) have also been identified by cDNA microarrays. ${ }^{133}$

\section{PROTEOMICS}

The system wide study of proteins presents an exciting challenge in this information rich age of whole genome biology. Although traditional investigations have yielded abundant information about individual proteins, they have been less successful at providing us with an integrated understanding of biological systems. The promise of proteomics is that, by studying many components simultaneously, we will learn how proteins interact with each other and with non-proteinaceous molecules, to control complex processes in cells, tissues, and even whole organisms.

Proteomics presents a new horizon for biomarker discovery and uses protein profiling technologies that can simultaneously resolve and analyse multiple proteins. The identification of proteomic patterns in serum has been used to distinguish neoplastic from non-neoplastic disease within the prostate.

Study cohorts of healthy controls, benign prostate neoplasia, and prostate cancer could be separated based on the overexpression or underexpression of nine protein masses. This study required only the mass values of the proteins using a protein biochip mass spectrometry approach, coupled with an artificial intelligence learning algorithm. Knowing the protein identities was not required for the purposes of differential diagnosis.

"Proteomics presents a new horizon for biomarker
discovery and uses protein profiling technologies that
can simultaneously resolve and analyse multiple proteins"

Efforts are under way to identify and characterise these peptide/protein biomarkers because this knowledge will be important in understanding what biological role they play in prostate cancer oncogenesis. ${ }^{147}{ }^{148}$ A protein known as growth differentiation factor 15 has been identified as a proteomic alteration in a recent study using laser capture microdissection, and may be involved in early prostate carcinogenesis. ${ }^{149}$ Downregulation of IFNs has also been identified by proteomic analysis. ${ }^{150}$ Proteomics is a very exciting molecular tool and studies to date have shown a higher specificity for prostate cancer than PSA screening.

\section{THE ROLE OF INFLAMMATION IN PROSTATE CANCER}

Inflammation has a role in many cancers. ${ }^{151}$ Symptomatic prostatitis occurs in at least $9 \%$ of men $>40$ years of age, many suffering from multiple episodes. ${ }^{152}$ The prevalence of asymptomatic prostatitis is not known. ${ }^{153}$ Inflammatory cells produce numerous oxidants with potential to cause cellular or genomic damage in the prostate. ${ }^{154}$ There is accumulating knowledge supporting the role of inflammation in prostate cancer, including epidemiological studies showing that there is a decreased risk of prostate cancer associated with the intake of antioxidants or non-steroidal anti-inflammatory drugs. ${ }^{155} 156$

In addition, epidemiological studies have shown an increased risk of prostate cancer associated with sexually transmitted infections, regardless of the particular infection, suggesting that it is the associated inflammation rather than a particular causal infection that is involved in prostate cancer. $^{157158}$

Molecular pathology studies also support the hypothesis that inflammation is important in the aetiology of prostate cancer. Two of the prostate cancer susceptibility genes identified thus far, RNASEL and MSRl, encode proteins with crucial functions in host responses to infections. In addition, a polymorphism of TLR4 is associated with an increased risk of prostate cancer. TLR4 encodes a receptor that is a central player in the signalling pathways of the innate immune response to infection by Gram negative bacteria. ${ }^{8} 1522$

Diagnostic histopathologists have also proposed that a prostatic lesion called proliferative inflammatory atrophy is a precursor of PIN and prostate cancer. 
The term proliferative inflammatory atrophy applies to focal atrophic lesions associated with chronic inflammation and often adjacent to foci of PIN or prostate cancer.

These lesions are thought to arise as a consequence of the regenerative proliferation of prostate epithelial cells in response to injury caused by inflammatory oxidants. ${ }^{159}$ Somatic genomic abnormalities similar to those in PIN and prostate cancer have been found in foci of proliferative inflammatory atrophy. ${ }^{160}$ Epithelial cells in lesions of proliferative inflammatory atrophy also show many molecular signs of stress, such as high concentrations of GSTPI, glutathione S-transferase Al, and cyclooxygenase 2. ${ }^{159} 161162$

\section{"The evidence for a role of inflammation in prostate cancer is convincing with support from epidemiological, molecular, and histopathological studies"}

Loss of GSTPl, probably as a result of hypermethylation of the CpG island sequences of GSTPl, may define the transition between proliferative inflammatory atrophy and PIN or prostate cancer. ${ }^{163-165}$

Phenotypically intermediate cells between basal and secretory cells have been identified in normal prostate epithelium and these cells are increased in proliferative inflammatory atrophy lesions. The finding of a large number of highly proliferating intermediate cells in proliferative inflammatory atrophy indicates that these cells may serve as preferred target cells in prostate carcinogenesis. ${ }^{166}$

The evidence for a role of inflammation in prostate cancer is convincing with support from epidemiological, molecular, and histopathological studies. In the near future it may be common practice for the prescription of anti-inflammatory drugs to decrease the risk of development of prostate cancer, just as the prescription of aspirin is common practice now to decrease the risk of stroke.

\section{Take home messages}

- The molecular pathology of prostate cancer is complex: many genes are involved in its pathogenesis and additional environmental factors such as diet and inflammation also play a role

- Epidemiologically, prostate cancer can be divided into hereditary and sporadic forms, but they cannot be distinguished molecularly and, unlike in many other cancers, highly penetrant inherited genes conferring the prostate cancer phenotype have not been identified

- Several polymorphisms have been associated both with increased risk of prostate cancer and with increased risk of progression

- Many somatic mutations and chromosomal abnormalities have been identified in prostate cancer, including overexpression of oncogenes, such as bcl-2, and underexpression of tumour suppressor genes, such as GSTP1, and changes in the expression of growth factors and their receptors

- The application of new investigative tools such as DNA microarray technology and proteomics to the study of prostate cancer should improve knowledge of the genetic changes underlying the initiation, development, and progression of this disease and hopefully help distinguish indolent from aggressive prostate tumours by molecular fingerprinting

\section{CONCLUSIONS}

Powerful new molecular pathology tools such as DNA microarrays are providing information that is already being incorporated into diagnostic pathology such as AMACR staining of prostate cancer cells. The molecular pathology of prostate cancer is complex; not only are multiple genes involved in its pathogenesis, but additional environmental factors such as diet and inflammation also play a role.

In other cancers such as colon cancer there are gatekeeper genes and multistep models of carcinogenesis. No such genes have been identified in prostate cancer despite exhaustive research. There is a complex interaction of multiple genes and environmental factors, some of which may be more important in individual patients with prostate cancer. This may explain why the molecular pathology findings in prostate cancer have not been useful in clinical practice to date; however, this looks likely to change.

\section{ACKNOWLEDGEMENTS}

The authors wish to thank the Meath Foundation, which sponsors prostate research in the department.

\section{Authors' affiliations}

C Hughes, A Murphy, C Martin, O Sheils, Pathology Department, Trinity College Dublin and Coombe Women's Hospital, Dublin, Ireland J O'Leary, Pathology Department, Coombe Women's Hospital, Dublin 8 , Ireland

\section{REFERENCES}

1 Sanchez-Chapado M, Olmedilla G, Cabeza M, et al. Prevalence of prostate cancer and prostatic intraepithelial neoplasia in Caucasian Mediterranean males: an autopsy study. Prostate 2003;3:238-47.

2 Toms J. Cancer incidence, survival and mortality in the UK and EU. UK: Cancer Stats Monograph 2004. London: Cancer Research UK, 2004.

3 Carter B, Bova G, Beaty T, et al. Hereditary prostate cancer: epidemiologic and clinical features. J Urol 1993;150:797-802.

4 DeMarzo AM, Nelson WG, Isaacs WB, et al. Pathological and molecular aspects of prostate cancer. Lancet 2003;361:955-64.

5 Rebbeck TR, Walker AH, Zeigler-Johnson C, et al. Association of HPC2/ ELAC2 genotypes and prostate cancer. Am J Hum Genet 2000;61:1014-19.

6 Suarez BK, Gerhard DS, Lin J, et al. Polymorphisms in the prostate cancer susceptibility gene HPC2/ELAC2 in multiplex families and healthy controls. Cancer Res 2001;61:4982-4.

7 Xu J, Zheng SL, Carpten JD, et al. Evaluation of linkage and association of HPC2/ELAC2 in patients with familial or sporadic prostate cancer. Am J Hum Genet 2001;68:901-11.

8 Carpten J, Nupponen N, Isaacs S, et al. Germline mutations in the ribonuclease $\mathrm{L}$ gene in families showing linkage with $\mathrm{HPCl}$. Nat Genet 2002;30:181-4.

9 Rokman A, Ikonen T, Seppala EH, et al. Germline alterations of the RNASEL gene, a candidate $\mathrm{HPCl}$ gene at $1 \mathrm{q} 25$, in patients and families with prostate cancer. Am J Hum Genet 2002;70:1299-304.

10 Rennert $H$, Bercovich $D$, Hubert $A$, et al. A novel founder mutation in the RNASEL gene, 471 delAAAG, is associated with prostate cancer in Ashkenazi Jews. Am J Hum Genet 2002;11:981-4.

11 Casey G, Neville PJ, Plummer SJ, et al. RNASEL Arg462Gln variant is implicated in up to $13 \%$ of prostate cancer cases. Nat Genet 2002;32:581-3.

12 Wang L, McDonnell SK, Elkins DA, et al. Analysis of the RNASEL gene in familial and sporadic prostate cancer. Am J Hum Genet 2002;71:116-23.

13 Withdrawn

14 Nakazato H, Suzuki K, Matsui H, et al. Role of genetic polymorphisms of the RNASEL gene on familial prostate cancer risk in a Japanese population. Br J Cancer 2003;89:691-6.

$15 \mathrm{Xu}$ J, Zheng SL, Komiya A, et al. Germline mutations and sequence variants of the macrophage scavenger receptor 1 gene are associated with prostate cancer risk. Nat Genet 2002;32:321-5.

16 Dejager S, Mietus-Snyder M, Friera A, et al. Dominant negative mutations of the scavenger receptor. Native receptor inactivation by expression of truncated variants. J Clin Invest 1993;92:894-902.

17 Wang L, McDonnell SK, Cunningham JM, et al. No association of germline alteration of MSR1 with prostate cancer risk. Nat Genet 2003;35:128-9.

18 Demuth I, Frappart PO, Hildebrand G, et al. An inducible null mutant murine model of Nijmegen breakage syndrome proves the essential function of NBS1 in chromosomal stability and cell viability. Hum Mol Genet 2004; 13:2385-97.

19 Cybulski C, Gorski B, Debniak T, et al. NBS1 is a prostate cancer susceptibility gene. Cancer Res 2004;64:1215-19.

20 Dong X, Wang L, Taniguchi K, et al. Mutations in CHEK2 associated with prostate cancer risk. Am J Hum Genet 2003;72:270-80. 
21 Cybulski C, Huzarski T, Gorski B, et al. A novel founder CHEK2 mutation is associated with increased prostate cancer risk. Cancer Res 2004;64:2677-9.

22 Zheng SL, Augustsson-Balter K, Chang B, et al. Sequence variants of toll-like receptor 4 are associated with prostate cancer risk: results from the prostate cancer in Sweden study. Cancer Res 2004;64:2918-22.

23 Chang BL, Zheng SL, Isaacs SD, et al. A polymorphism in the CDKN1B gene is associated with increased risk of hereditary prostate cancer. Cancer Res 2004;64:1997-9.

24 Kibel AS, Suarez BK, Belani J, et al. CDKN1A and CDKN1B polymorphisms and risk of advanced prostate carcinoma. Cancer Res 2003;63:2033-6.

25 Giovannucci E, Stampfer MJ, Krithivas K, et al. The CAG repeat within the androgen receptor gene and its relationship to prostate cancer. Proc Natl Acad Sci U S A 1997;94:3320-3.

26 Stanford JL, Just JJ, Gibbs $M$, et al. Polymorphic repeats in the androgen receptor gene: molecular markers of prostate cancer risk. Cancer Res 1997; 57:1194-8.

27 Freedman ML, Pearce CL, Penney KL, et al. Systematic evaluation of genetic variation at the androgen receptor locus and risk of prostate cancer in a multiethnic cohort study. Am J Hum Genet 2005;76:82-90.

28 Zeegers MP, Kiemeney LA, Nieder AM, et al. How strong is the association between $C A G$ and $G G N$ repeat length polymorphisms in the androgen receptor gene and prostate cancer risk? Cancer Epidemiol Biomarkers Prev 2004; 13:1765-71.

29 Chang B, Zheng SL, Isaacs SD, et al. Linkage and association of CYP17 gene in hereditary and sporadic prostate cancer. Int J Cancer 2001;95:354-9.

30 Stanford JL, Noonan EA, Iwasaki L, et al. A polymorphism in the CYP17 gene and risk of prostate cancer. Cancer Epidemiol Biomarkers Prev 2002; 11:243-7.

31 Makridakis NM, Ross RK, Pike MC, et al. Association of mis-sense substitution in SRD5A2 gene with prostate cancer in African-American and Hispanic men in Los Angeles, USA. Lancet 1999;354:975-8.

32 Nam RK, Toi A, Vesprini D, et al. V89L polymorphism of type-2, 5-alpha reductase enzyme gene predicts prostate cancer presence and progression. Urology 2001;57:199-204.

33 Skowronski RJ, Peehl DM, Feldman D. Vitamin D and prostate cancer: 1,25 dihydroxyvitamin D3 receptors and actions in human prostate cancer cell lines. Endocrinology 1993;132:1952-60.

34 Morrison NA, Yeoman R, Kelly PJ, et al. Contribution of trans-acting factor alleles to normal physiological variability: vitamin $D$ receptor gene polymorphism and circulating osteocalcin. Proc Natl Acad Sci U S A 1992;89:6665-9.

35 Ingles SA, Ross RK, Yu MC, et al. Association of prostate cancer risk with genetic polymorphisms in vitamin D receptor and androgen receptor. J Natl Cancer Inst 1997;89:166-70.

36 Chen C. Risk of prostate cancer in relation to polymorphisms of metabolic genes. Epidemiol Rev 2001;23:30-5.

37 Abate-Shen C, Shen MM. Molecular genetics of prostate cancer. Genes Dev 2000;14:2410-34.

38 Elo JP, Visakorpi T. Molecular genetics of prostate cancer. Ann Med 2001;33:130-41.

39 Matsuura $\mathrm{H}$, Shiraishi T, Yatani R, et al. Interphase cytogenetics of prostate cancer: fluorescence in situ hybridisation (FISH) analysis of Japanese cases. Br J Cancer 1996;74:1699-704.

40 Yang G, Truong LD, Wheeler TM, et al. Caveolin-1 expression in clinically confined human prostate cancer: a novel prognostic marker. Cancer Res 1999;59:5719-23.

41 Matsuyama H, Pan Y, Oba K, et al. Deletions on chromosome 8p22 may predict disease progression as well as pathological staging in prostate cancer. Clin Cancer Res 2001;7:3139-43.

42 Bowen C, Bubendorf L, Voeller HJ, et al. Loss of NKX3.1 expression in human prostate cancers correlates with tumor progression. Cancer Res 2000;60:6111-15

43 Jenkins RB, Qian J, Lieber MM, et al. Detection of c-myc oncogene amplification and chromosomal anomalies in metastatic prostatic carcinoma by fluorescence in situ hybridization. Cancer Res 1997;57:524-31.

44 McMenamin ME, Soung P, Perera S, et al. Loss of PTEN expression in paraffin-embedded primary prostate cancer correlates with high Gleason score and advanced stage. Cancer Res 1999;59:4291-6.

45 Phillips SM, Barton CM, Lee SJ, et al. Loss of the retinoblastoma susceptibility gene (RB1) is a frequent and early event in prostatic tumorigenesis. Br J Cancer 1994; 70:1252-7.

46 Paul R, Ewing CM, Jarrard DF, et al. The cadherin cell-cell adhesion pathway in prostate cancer progression. Br J Urol 1997;79(suppl 1):37-43.

47 Brinkmann AO, Kuiper GG, Ris-Stalpers C, et al. Androgen receptor abnormalities. J Steroid Biochem Mol Biol 1991;40:349-52.

48 Knudson AG Jr. Genetic predisposition to cancer. Cancer Detect Prev 1984;7:1-8.

49 Jones PA, Laird PW. Cancer epigenetics comes of age. Nat Genet 1999;21:163-7

50 Bookstein R. Tumour suppressor genes in prostate cancer. In: Totowa NJ, ed. Prostate cancer: biology genetics and the new therapeutics. Humana Press, 2001:61-93.

51 Nelson WG, De Marzo AM, Deweese TL, et al. Preneoplastic prostate lesions: an opportunity for prostate cancer prevention. Ann NY Acad Sci 2001:952:135-44

52 Lee WH, Morton RA, Epstein Jl, et al. Cytidine methylation of regulatory sequences near the pi-class glutathione $S$-transferase gene accompanies human prostatic carcinogenesis. Proc Natl Acad Sci U S A 1994;91:11733-7
53 Millar DS, Ow KK, Paul CL, et al. Detailed methylation analysis of the glutathione S-transferase pi (GSTP1) gene in prostate cancer. Oncogene 1999; 18:1313-24.

54 Harden SV, Guo Z, Epstein Jl, et al. Quantitative GSTP1 methylation clearly distinguishes benign prostatic tissue and limited prostate adenocarcinoma. $J$ Urol 2003;169:1138-42.

55 Yegnasubramanian S, Kowalski J, Gonzalgo ML, et al. Hypermethylation of $\mathrm{CpG}$ islands in primary and metastatic human prostate cancer. Cancer Res 2004;64:1975-86.

56 Suzuki H, Freije D, Nusskern DR, et al. Interfocal heterogeneity of PTEN/ $\mathrm{MMACl}$ gene alterations in multiple metastatic prostate cancer tissues. Cancer Res 1998;58:204-9.

57 Vivanco I, Sawyers CL. The phosphatidylinositol 3-kinase AKT pathway in human cancer. Nat Rev Cancer 2002;2:489-501.

58 Sun H, Lesche R, Li DM, et al. PTEN modulates cell cycle progression and cell survival by regulating phosphatidylinositol 3,4,5,-trisphosphate and Akt/ protein kinase B signaling pathway. Proc Natl Acad Sci U S A 1999:96:6199-204.

59 Cote RJ, Shi Y, Groshen S, et al. Association of p27Kipl levels with recurrence and survival in patients with stage $C$ prostate carcinoma. J Natl Cancer Inst 1998;90:916-20.

60 De Marzo AM, Meeker AK, Epstein Jl, et al. Prostate stem cell compartments: expression of the cell cycle inhibitor p27Kipl in normal, hyperplastic, and neoplastic cells. Am J Pathol 1998;153:911-19.

61 Kibel AS, Faith DA, Bova GS, et al. Loss of heterozygosity at 12P12-13 in primary and metastatic prostate adenocarcinoma. J Urol 2000;164:192-6.

62 Nakamura N, Ramaswamy S, Vazquez F, et al. Forkhead transcription factors are critical effectors of cell death and cell cycle arrest downstream of PTEN. Mol Cell Biol 2000;20:8969-82.

63 Chen H, Nandi AK, Li X, et al. NKX-3.1 interacts with prostate-derived Ets factor and regulates the activity of the PSA promoter. Cancer Res 2002;62:338-40.

64 Chen C, Hyytinen ER, Sun X, et al. Deletion, mutation, and loss of expression of KLF6 in human prostate cancer. Am J Pathol 2003;162:1349-54.

65 Narla G, Heath KE, Reeves HL, et al. KLF6, a candidate tumor suppressor gene mutated in prostate cancer. Science $2001 ; 294: 2563-6$.

66 Bookstein R, Rio P, Madreperla SA, et al. Promoter deletion and loss of retinoblastoma gene expression in human prostate carcinoma. Proc Natl Acad Sci U S A 1990;87:7762-6.

67 Brooks JD, Bova GS, Isaacs WB. Allelic loss of the retinoblastoma gene in primary human prostatic adenocarcinomas. Prostate 1995;26:35-9.

68 Bookstein R, Shew JY, Chen PL, et al. Suppression of tumorigenicity of human prostate carcinoma cells by replacing a mutated RB gene. Science 1990;247:712-15

69 Tricoli JV, Gumerlock PH, Yao JL, et al. Alterations of the retinoblastoma gene in human prostate adenocarcinoma. Genes Chromosomes Cancer 1996;15:108-14.

70 Lalani el N, Laniado ME, Abel PD. Molecular and cellular biology of prostate cancer. Cancer Metastasis Rev 1997;16:29-66.

71 Gao X, Porter AT, Grignon DJ, et al. Diagnostic and prognostic markers for human prostate cancer. Prostate 1997;31:264-81.

72 Grignon DJ, Caplan R, Sarkar FH, et al. p53 status and prognosis of locally advanced prostatic adenocarcinoma: a study based on RTOG 8610. J Natl Cancer Inst 1997;89:158-65.

73 Buttyan R, Sawczuk IS, Benson MC, et al. Enhanced expression of the c-myc protooncogene in high-grade human prostate cancers. Prostate 1987; 1 1:327-37

74 Qian J, Hirasawa K, Bostwick DG, et al. Loss of p53 and c-myc overrepresentation in stage $\mathrm{T}(2-3) \mathrm{N}(1-3) \mathrm{M}(0)$ prostate cancer are potential markers for cancer progression. Mod Pathol 2002;15:35-44

75 Tsuchiya N, Slezak JM, Lieber MM, et al. Clinical significance of alterations of chromosome 8 detected by fluorescence in situ hybridization analysis in pathologic organ-confined prostate cancer. Genes Chromosomes Cancer 2002;34:363-71.

76 Krajewska M, Krajewski S, Epstein J, et al. Immunohistochemical analysis of $\mathrm{bcl}-2$, bax, bcl-X, and $\mathrm{mcl}-1$ expression in prostate cancers. Am J Pathol 1996; 148:1567-76

77 Bubendorf L, Sauter G, Moch H, et al. Prognostic significance of Bcl-2 in clinically localized prostate cancer. Am J Pathol 1996;148:1557-65.

78 Moul JW, Bettencourt MC, Sesterhenn IA, et al. Protein expression of p53 bcl-2, and $\mathrm{KI}-67$ (MIB-1) as prognostic biomarkers in patients with surgically treated, clinically localized prostate cancer. Surgery 1996;120:159-66.

79 Catz SD, Johnson JL. BCL-2 in prostate cancer: a minireview. Apoptosis 2003;8:29-37.

80 McDonnell TJ, Troncoso P, Brisbay SM, et al. Expression of the protooncogene bcl-2 in the prostate and its association with emergence of androgen-independent prostate cancer. Cancer Res 1992;52:6940-4

81 Paronetto MP, Farini D, Sammarco l, et al. Expression of a truncated form of the c-Kit tyrosine kinase receptor and activation of Src kinase in human prostatic cancer. Am J Pathol 2004; 164:1243-51.

82 Kazansky AV, Spencer DM, Greenberg NM. Activation of signal transducer and activator of transcription 5 is required for progression of autochthonous prostate cancer: evidence from the transgenic adenocarcinoma of the mouse prostate system. Cancer Res 2003;63:8757-62.

$83 \mathrm{Li} \mathrm{H}$, Ahonen TJ, Alanen K, et al. Activation of signal transducer and activator of transcription 5 in human prostate cancer is associated with high histological grade. Cancer Res 2004;64:4774-82.

84 Zakian VA. Telomeres: beginning to understand the end. Science 1995;270:1601-7.

85 Lin Y, Uemura H, Fujinami K, et al. Telomerase activity in primary prostate cancer. J Urol 1997;157:1161-5. 
86 Sommerfeld HJ, Meeker AK, Piatyszek MA, et al. Telomerase activity: a prevalent marker of malignant human prostate tissue. Cancer Res 1996;56:218-22.

87 Veldscholte J, Ris-Stalpers C, Kuiper GG, et al. A mutation in the ligand binding domain of the androgen receptor of human LNCaP cells affects steroid binding characteristics and response to anti-androgens. Biochem Biophys Res Commun 1990;173:534-40.

88 Tilley WD, Wilson CM, Marcelli $M$, et al. Androgen receptor gene expression in human prostate carcinoma cell lines. Cancer Res 1990;50:5382-6.

89 Visakorpi T, Hyytinen E, Koivisto $P$, et al. In vivo amplification of the androgen receptor gene and progression of human prostate cancer. Nat Genet 1995;9:401-6.

90 Taplin ME, Bubley GJ, Shuster TD, et al. Mutation of the androgen-receptor gene in metastatic androgen-independent prostate cancer. N Engl J Med 1995;332:1393-8.

91 Klocker H, Culig Z, Kaspar F, et al. Androgen signal transduction and prostatic carcinoma. World J Urol 1994; 12:99-103.

92 Shi XB, Ma AH, Xia L, et al. Functional analysis of 44 mutant androgen receptors from human prostate cancer. Cancer Res 2002;62:1496-502.

93 Bakin RE, Gioeli D, Sikes RA, et al. Constitutive activation of the Ras/ mitogen-activated protein kinase signaling pathway promotes androgen hypersensitivity in LNCaP prostate cancer cells. Cancer Res 2003;63:1981-9.

94 Ware JL. Growth factors and their receptors as determinants in the proliferation and metastasis of human prostate cancer. Cancer Metastasis Rev 1993;12:287-301

95 Steiner H, Godoy-Tundidor S, Rogatsch H, et al. Accelerated in vivo growth of prostate tumors that up-regulate interleukin- 6 is associated with reduced retinoblastoma protein expression and activation of the mitogen-activated protein kinase pathway. Am J Pathol 2003;162:655-63

96 Sivashanmugam P, Tang L, Daaka Y. Interleukin 6 mediates the lysophosphatidic acid-regulated cross-talk between stromal and epithelial prostate cancer cells. J Biol Chem 2004;279:21154-9.

97 Rajan R, Vanderslice R, Kapur S, et al. Epidermal growth factor (EGF) promotes chemomigration of a human prostate tumor cell line, and EGF immunoreactive proteins are present at sites of metastasis in the stroma of lymph nodes and medullary bone. Prostate 1996;28:1-9.

98 Kostenuik PJ, Singh G, Orr FW. Transforming growth factor beta upregulates the integrin-mediated adhesion of human prostatic carcinoma cells to type I collagen. Clin Exp Metastasis 1997;15:41-52.

99 Peehl DM, Cohen P, Rosenfeld RG. The insulin-like growth factor system in the prostate. World J Urol 1995;13:306-11.

100 Sakr WA, Grignon DJ. Prostate cancer: indicators of aggressiveness. Eur Urol 1997;32(suppl 3):15-23.

101 Harper ME, Glynne-Jones E, Goddard L, et al. Vascular endothelial growth factor (VEGF) expression in prostatic tumours and its relationship to neuroendocrine cells. Br J Cancer 1996;74:910-16.

102 Skacel M, Ormsby AH, Pettay JD, et al. Aneusomy of chromosomes 7, 8, and 17 and amplification of HER-2/neu and epidermal growth factor receptor in Gleason score 7 prostate carcinoma: a differential fluorescent in situ hybridization study of Gleason pattern 3 and 4 using tissue microarray. Hum Pathol 2001;32:1392-7.

103 Ross JS, Sheehan CE, Hayner-Buchan AM, et al. Prognostic significance of HER-2/neu gene amplification status by fluorescence in situ hybridization of prostate carcinoma. Cancer 1997;79:2162-70.

104 Ross JS, Sheehan C, Hayner-Buchan AM, et al. HER-2/neu gene amplification status in prostate cancer by fluorescence in situ hybridization. Hum Pathol 1997; 28:827-33.

105 Savinainen KJ, Saramaki OR, Linja MJ, et al. Expression and gene copy number analysis of ERBB2 oncogene in prostate cancer. Am J Pathol 2002; 160:339-45.

106 Bubendorf L, Kononen J, Koivisto $P$, et al. Survey of gene amplifications during prostate cancer progression by high-throughout fluorescence in situ hybridization on tissue microarrays. Cancer Res 1999;59:803-6.

107 Sanchez KM, Sweeney CJ, Mass R, et al. Evaluation of HER-2/neu expression in prostatic adenocarcinoma: a request for a standardized, organ specific methodology. Cancer 2002;95:1650-5.

108 Signoretti S, Montironi R, Manola J, et al. Her-2-neu expression and progression toward androgen independence in human prostate cancer. $J$ Natl Cancer Inst 2000;92:1918-25.

109 Reese DM, Small EJ, Magrane G, et al. HER2 protein expression and gene amplification in androgen-independent prostate cancer. Am J Clin Pathol $2001 ; 116: 234-9$

110 Lara PN Jr, Meyers FJ, Gray CR, et al. HER-2/neu is overexpressed infrequently in patients with prostate carcinoma. Results from the California cancer consortium screening trial. Cancer 2002;94:2584-9.

111 Calvo BF, Levine AM, Marcos M, et al. Human epidermal receptor-2 expression in prostate cancer. Clin Cancer Res 2003;9:1087-97.

112 Withdrawn

113 Jiang J, Ulbright TM, Zhang S, et al. Fas and Fas ligand expression is elevated in prostatic intraepithelial neoplasia and prostatic adenocarcinoma. Cancer 2002;95:296-300.

114 Humphrey PA, Zhu X, Zarnegar R, et al. Hepatocyte growth factor and its receptor (c-MET) in prostatic carcinoma. Am J Pathol 1995; 147:386-96.

115 Knudsen BS, Gmyrek GA, Inra J, et al. High expression of the Met recepto in prostate cancer metastasis to bone. Urology 2002;60:1113-17.

116 Fujiuchi Y, Nagakawa O, Murakami K, et al. Effect of hepatocyte growth factor on invasion of prostate cancer cell lines. Oncol Rep 2003;10:1001-6.
117 Umbas R, Isaacs WB, Bringuier PP, et al. Decreased E-cadherin expression is associated with poor prognosis in patients with prostate cancer. Cancer Res 1994;54:3929-33

118 Umbas R, Schalken JA, Aalders TW, et al. Expression of the cellular adhesion molecule E-cadherin is reduced or absent in high-grade prostate cancer. Cancer Res 1992;52:5104-9.

119 Ross JS, Figge HL, Bui HX, et al. E-cadherin expression in prostatic carcinoma biopsies: correlation with tumor grade, DNA content, pathologic stage, and clinical outcome. Mod Pathol 1994;7:835-41.

120 Rubin MA, Mucci NR, Figurski J, et al. E-cadherin expression in prostate cancer: a broad survey using high-density tissue microarray technology. Hum Pathol 2001;32:690-7.

121 Cress AE, Rabinovitz I, Zhu W, et al. The alpha 6 beta 1 and alpha 6 beta 4 integrins in human prostate cancer progression. Cancer Metastasis Rev 1995; 14:219-28.

122 Fornaro $M$, Manes T, Languino LR. Integrins and prostate cancer metastases. Cancer Metastasis Rev 2001;20:321-31.

123 Lang SH, Clarke NW, George NJ, et al. Primary prostatic epithelial cell binding to human bone marrow stroma and the role of alpha2betal integrin. Clin Exp Metastasis 1997; 15:218-27.

124 Kleinerman DI, Troncoso P, Lin SH, et al. Consistent expression of an epithelial cell adhesion molecule (C-CAM) during human prostate development and loss of expression in prostate cancer: implication as a tumor suppressor. Cancer Res 1995;55:1215-20.

125 Lin SH, Pu YS. Function and therapeutic implication of C-CAM cell-adhesion molecule in prostate cancer. Semin Oncol 1999;26:227-33.

126 Jaeger EB, Samant RS, Rinker-Schaeffer CW. Metastasis suppression in prostate cancer. Cancer Metastasis Rev 2001;20:279-86.

127 Dong JT, Suzuki H, Pin SS, et al. Down-regulation of the KAll metastasis suppressor gene during the progression of human prostatic cancer infrequently involves gene mutation or allelic loss. Cancer Res 1996;56:4387-90.

128 Dong JT, Lamb PW, Rinker-Schaeffer CW, et al. KAll, a metastasis suppressor gene for prostate cancer on human chromosome $11 \mathrm{pl} 1.2$. Science 1995;268:884-6.

129 Zhang XA, Lane WS, Charrin S, et al. EWI2/PGRL associates with the metastasis suppressor KAll/CD82 and inhibits the migration of prostate cancer cells. Cancer Res 2003;63:2665-74.

130 Gao AC, Lou W, Dong JT, et al. CD44 is a metastasis suppressor gene for prostatic cancer located on human chromosome $11 \mathrm{p} 13$. Cancer Res 1997:57:846-9.

131 Kallakury BV, Yang F, Figge J, et al. Decreased levels of CD44 protein and mRNA in prostate carcinoma. Correlation with tumor grade and ploidy. Cancer 1996;78:1461-9.

132 Magee JA, Araki T, Patil S, et al. Expression profiling reveals hepsin overexpression in prostate cancer. Cancer Res 2001;61:5692-6.

133 Dhanasekaran SM, Barrette TR, Ghosh D, et al. Delineation of prognostic biomarkers in prostate cancer. Nature 2001;412:822-6.

134 Rubin MA, Zhou M, Dhanasekaran SM, et al. Alpha-methylacyl coenzyme A racemase as a tissue biomarker for prostate cancer. JAMA 2002;287:1662-70.

135 Giovannucci E, Rimm EB, Colditz GA, et al. A prospective study of dietary fat and risk of prostate cancer. J Natl Cancer Inst 1993;85:1571-9.

136 Luo J, Zha S, Gage WR, et al. Alpha-methylacyl-CoA racemase: a new molecular marker for prostate cancer. Cancer Res 2002;62:2220-6.

137 Kuefer R, Varambally S, Zhou M, et al. Alpha-methylacyl-CoA racemase: expression levels of this novel cancer biomarker depend on tumor differentiation. Am J Pathol 2002;161:841-8

138 Evans AJ. Alpha-methylacyl CoA racemase (P504S): overview and potential uses in diagnostic pathology as applied to prostate needle biopsies. J Clin Pathol 2003;56:892-7.

139 Hofer MD, Kuefer R, Varambally S, et al. The role of metastasis-associated protein 1 in prostate cancer progression. Cancer Res 2004;64:825-9.

140 Varambally S, Dhanasekaran SM, Zhou M, et al. The polycomb group protein EZH2 is involved in progression of prostate cancer. Nature 2002;419:624-9

141 Zhou H, Kuang J, Zhong L, et al. Tumour amplified kinase STK15/BTAK induces centrosome amplification, aneuploidy and transformation. Nat Genet 1998;20:189-93.

142 Bar-Shira A, Pinthus JH, Rozovsky U, et al. Multiple genes in human 20q13 chromosomal region are involved in an advanced prostate cancer xenograft. Cancer Res 2002;62:6803-7.

143 Shou J, Soriano R, Hayward, et al. Expression profiling of a human cell line model of prostatic cancer reveals a direct involvement of interferon signalling in prostate tumor progression. Proc Natl Acad Sci U S A 2002;5:2830-5.

144 Liu JW, Shen JJ, Tanzillo-Swrts A, et al. Annexin II expression is reduced or lost in prostate cancer cells and its re-expression inhibits prostate cancer cell migration. Oncogene 2003;10:1475-85.

145 Xin W, Rhodes DR, Ingold C, et al. Dysregulation of the annexin protein family is associated with prostate cancer progression. Am J Pathol 2003; 162:255-61

146 Huusko P, Ponciano-Jackson D, Wolf $M$, et al. Nonsense-mediated decay microarray analysis identifies mutations of EPHB2 in human prostate cancer Nat Genet 2004;36:937-8

147 Adam BL, Qu Y, Davis JW, et al. Serum protein fingerprinting coupled with a pattern-matching algorithm distinguishes prostate cancer from benign prostate hyperplasia and healthy men. Cancer Res 2002;62:3609-14.

148 Cazares LH, Adam BL, Ward MD, et al. Normal, benign, preneoplastic, and malignant prostate cells have distinct protein expression profiles resolved by surface enhanced laser desorption/ionization mass spectrometry. Clin Cancer Res 2002;8:2541-52. 
149 Cheung PK, Woolcock B, Adomat H, et al. Protein profiling of microdissected prostate tissue links growth differentiation factor 15 to prostate carcinogenesis. Cancer Res 2004;64:5929-33.

150 Nagano K, Masters JR, Akpan A, et al. Down-regulation of several interferon inducible proteins has also been identified by proteomic analysis. Differential protein synthesis and expression levels in normal and neoplastic human prostate cells and their regulation by type I and II interferons. Oncogene 2004;9:1693-703

151 Gardner WA Jr, Bennett BD. The prostate-overview: recent insights and speculations. Monogr Pathol 1992:129-48.

152 Roberts RO, Lieber MM, Rhodes T, et al. Prevalence of a physician-assigned diagnosis of prostatitis: the Olmsted County study of urinary symptoms and health status among men. Urology 1998;51:578-84.

153 Giovannucci E. Medical history and etiology of prostate cancer. Epidemiol Rev 2001;23:159-62.

154 Eiserich JP, Hristova M, Cross CE, et al. Formation of nitric oxide-derived inflammatory oxidants by myeloperoxidase in neutrophils. Nature 1998;391:393-7.

155 Clark LC, Dalkin B, Krongrad A, et al. Decreased incidence of prostate cancer with selenium supplementation: results of a double-blind cancer prevention trial. Br J Urol 1998;81:730-4.

156 Nelson JE, Harris RE. Inverse association of prostate cancer and nonsteroidal anti-inflammatory drugs (NSAIDs): results of a case-control study. Oncol Rep 2000;7:169-70.

157 Dennis LK, Dawson DV. Meta-analysis of measures of sexual activity and prostate cancer. Epidemiology 2002;13:72-9.

158 Hayes RB, Pottern LM, Strickler H, et al. Sexual behaviour, STDs and risks for prostate cancer. Br J Cancer 2000;82:718-25.
159 De Marzo AM, Marchi VL, Epstein Jl, et al. Proliferative inflammatory atrophy of the prostate: implications for prostatic carcinogenesis. Am J Pathol 1999; 155:1985-92.

160 Shah R, Mucci NR, Amin A, et al. Postatrophic hyperplasia of the prostate gland: neoplastic precursor or innocent bystander? Am J Pathol 2001; 158:1767-73.

161 Parsons JK, Nelson CP, Gage WR, et al. GSTA1 expression in normal, preneoplastic, and neoplastic human prostate tissue. Prostate 2001;49:30-7.

162 Zha S, Gage WR, Sauvageot J, et al. Cyclooxygenase-2 is up-regulated in proliferative inflammatory atrophy of the prostate, but not in prostate carcinoma. Cancer Res 2001;61:8617-23.

163 Jeronimo C, Henrique R, Hoque MO, et al. Quantitative RARbeta2 hypermethylation: a promising prostate cancer marker. Clin Cancer Res 2004;10:4010-14.

164 Nakayama M, Bennett CJ, Hicks JL, et al. Hypermethylation of the human glutathione S-transferase-pi gene (GSTP1) CpG island is present in a subset of proliferative inflammatory atrophy lesions but not in normal or hyperplastic epithelium of the prostate: a detailed study using laser-capture microdissection. Am J Pathol 2003;163:923-33.

165 Putzi MJ, De Marzo AM. Morphologic transitions between proliferative inflammatory atrophy and high-grade prostatic intraepithelial neoplasia. Urology 2000;56:828-32.

166 van Leenders GJ, Gage WR, Hicks JL, et al. Intermediate cells in human prostate epithelium are enriched in proliferative inflammatory atrophy. Am J Pathol 2003;162:1529-37. 